\title{
Four New Cardinalfishes (Perciformes: Apogonidae) from the Marquesas Islands ${ }^{1}$
}

\begin{abstract}
Jobn E. Randall ${ }^{2}$
Abstract: Four species of apogonid fishes are described as new from the Marquesas Islands. Apogon lativittatus, similar to A. semiornatus, differs in having 13 instead of 12 pectoral rays, 4.5-5.5 scales above the lateral line, 19-23 circumpeduncular scales, a straighter dorsal profile of the head, deeper body on the average, opaque red color as an adult with the same midlateral blackish stripe posteriorly on the body and caudal fin, but the oblique dark band on head reduced, and in larger size (to $58.4 \mathrm{~mm} \mathrm{SL}$ ); the type specimens include one from the Line Islands ( $A$. semiornatus remains unknown from islands of Oceania). Apogon relativus, with five dark stripes and pink fins, is similar to $A$. angustatus, differing in having narrower stripes, a larger and vertically elongate black spot at midbase of caudal fin in adults, and a broader interorbital space (bony width 4.05-4.8 in head, compared with 5.0-5.95 for A. angustatus). Apogon sinus, collected in very shallow water at the head of deep bays, is uniquely colored with seven narrow dark stripes on the body, but none on the lower third of body anterior to the caudal peduncle; it is most similar to the wide-ranging allopatric A. taeniophorus, from which it differs in a deeper body (2.6-2.9 in SL, compared with 2.8-3.2), broader interorbital space (4.2-4.45 in head, compared with 4.55.35), and in having 16-17 instead of 17-19 gill rakers. Pseudamiops phasma is described from two specimens. Like the three other species of the genus, it is elongate and compressed, with deciduous cycloid scales, no lateral line, ventral spine posteriorly on the maxilla, and largely transparent body; it differs variously from the others, but from all in having 19 compared with $14-18$ pectoral rays.
\end{abstract}

The FISH FaUna of the Marquesas Islands in the South Pacific, the northernmost archipelago of French Polynesia, is relatively impoverished. Only 415 species of shore fishes are known from these islands (Randall and Earle in press), compared with 633 for the Society Islands (Randall 1985, revised by Myers 1999). Although there has probably been more fish collecting in the Societies, it is very evident that there are fewer fishes in the Marquesas when one compares the number of species in families of which the species are readily observed and collected. For example,

\footnotetext{
${ }^{1}$ Manuscript accepted 2 March 2000.

2 Bishop Museum, 1525 Bernice Street, Honolulu, Hawai'i 96817-2704.
}

Pacific Science (2001), vol. 55, no. 1:47-64 (C) 2001 by University of Hawai'i Press All rights reserved the Society Islands has 27 chaetodontids, 11 pomacanthids, 33 pomacentrids, 50 labrids, and 19 scarids. The respective numbers for these families in the Marquesas are 15, 3, 21, 33 , and 6.

The Marquesas are also special in having the third highest level of endemism of shore fishes in the Pacific, 11.6\% (Randall and Earle in press), after Hawai'i with $23.1 \%$ and Easter Island with $22.2 \%$ (Randall 1998). The basis for the high endemism of the Marquesas appears to be their isolation and variable sea temperature.

The Marquesas lie between latitude $7^{\circ} 50^{\prime} \mathrm{S}$ and $10^{\circ} 35^{\prime} \mathrm{S}$ and longitude $138^{\circ}$ $25^{\prime} \mathrm{W}$ and $140^{\circ} 50^{\prime} \mathrm{W}$. They are high islands of volcanic origin that rise steeply from the sea bottom at depths greater than $4000 \mathrm{~m}$. There are no barrier reefs, hence no lagoons, and relatively little live coral. The sea-surface temperature for the region from 1982 to 1998 averaged $27.5^{\circ} \mathrm{C}$, with extremes 
of 26.5 and $30.0^{\circ} \mathrm{C}$. This is a large range of open-ocean sea temperature for a locality so near the equator. The cooler temperature is from equatorial upwelling, and the higher temperature from El Niño. The warming from El Niño would result in a greater temperature change in the Marquesas than at other low-latitude islands to the west. If the sea-surface temperature were as high as $30^{\circ} \mathrm{C}$ in the open ocean, still higher sea temperature would be expected at times inshore, depending on other factors such as circulation and diurnal heating.

The nearest islands to the Marquesas are the atolls of the northern Tuamotu Archipelago some $500 \mathrm{~km}$ to the southwest. There is no evidence that they were ever any closer than they are today (Springer 1982). The nearest islands to the east are the Galápagos, about $3700 \mathrm{~km}$ away. Because the prevailing current, the South Equatorial, flows from east to west, any larval forms from the Galápagos or coast of South America would have to be transported an immense distance to reach the Marquesas. As would be expected, the Marquesan shore fish fauna is dominantly tropical Indo-Pacific in origin, with an endemic component of Indo-Pacific faunal affinity.

The percentage of endemics varies greatly from family to family. In general, the families with pelagic larvae of relatively large size have few or no native species. The moray eel family Muraenidae is an example, with 34 Marquesan species and no endemics. The families that lay demersal eggs such as the damselfishes (Pomacentridae) and gobies (Gobiidae) or have oral incubation of the eggs such as the cardinalfishes (Apogonidae) have more endemic species (seven of 21 pomacentrids and six of 14 apogonids are found only in the Marquesas).

The purpose of this paper is to describe four of the Marquesan apogonids, three in the genus Apogon and one in Pseudamiops. A fourth new species of Apogon, a transparent red fish allied to $A$. erythrinus, is being described by David W. Greenfield of the University of Hawai'i, and a new species of Gymnapogon is under study by Jeng-Ping Chen of the Institute of Zoology, Academia Sinica, Taiwan.

\section{MATERIALS AND METHODS}

Specimens of the new species of apogonid fishes were deposited variously at the following institutions: Academy of Natural Sciences of Philadelphia (ANSP); Australian Museum, Sydney (AMs); Bernice P. Bishop Museum, Honolulu (вPBM); California Academy of Sciences, San Francisco (CAS); Field Museum of Natural History, Chicago (FMNH); Museum National d'Histoire Naturelle, Paris (MNHN); National Science Museum, Tokyo (NSMT); and U.S. National Museum of Natural History, Washington, D.C. (USNM).

Lengths given for specimens are standard length (SL), the straight-line distance from the most anterior point of the snout or upper lip to the base of the caudal fin (posterior end of the hypural plate). Head length is measured from the same median anterior point to the most posterior end of the opercular membrane, and snout length from the same point to the fleshy edge of the orbit. Body depth is the maximum depth from the base of the spines of the first dorsal fin, and body width the greatest width just posterior to the gill opening. Orbit diameter is the greatest fleshy diameter, and interorbital width the least bony width. Caudal-peduncle depth is the least depth, and caudal-peduncle length is measured horizontally from the rear base of the anal fin to the caudal-fin base. Lengths of fin spines and soft rays are taken to their extreme base. Caudal concavity (for species with emarginate or forked caudal fins) is the horizontal distance between verticals at the tips of the shortest and longest caudal rays.

Pectoral-ray counts include the upper rudimentary ray. Lateral-line scales are counted from the upper end of the gill opening to the base of the caudal fin (a separate count may be given of the few pored scales that lie on the base of the caudal fin). Gill-raker counts include rudiments; the upper-limb count is given first, and the raker at the angle is contained in the lower-limb count. Developed rakers are defined as those that are higher than the greatest width of their base.

Proportional measurements are presented in separate tables for each species as percentages of the standard length. Body and fin 


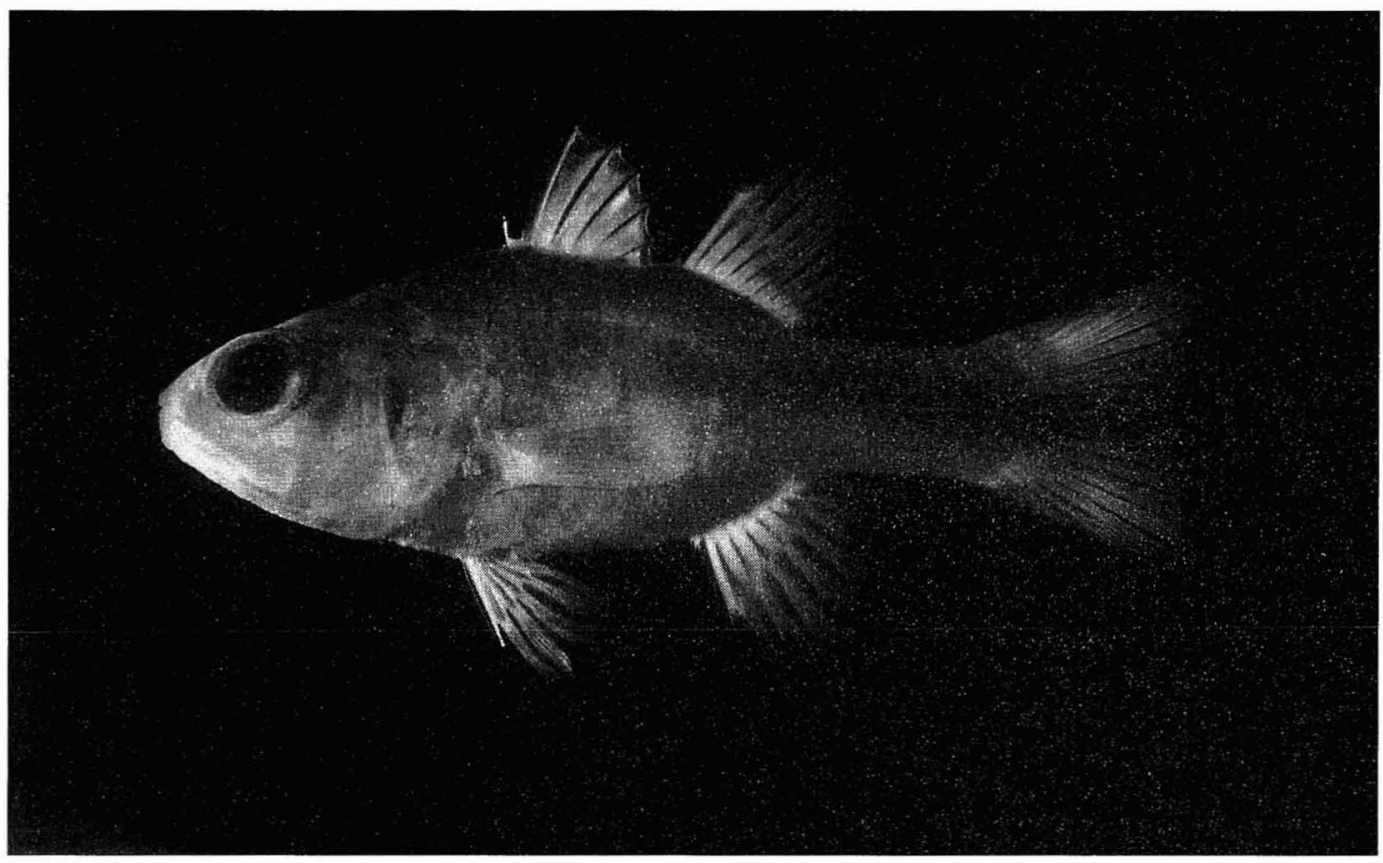

Figure 1. Holotype of Apogon lativittatus, врвм 11665, 54.3 mm, Fatu Hiva, Marquesas Islands.

proportions in the text are step-in measurements rounded to the nearest 0.05 . Data in parentheses in the descriptions refer to paratypes if different from the holotype.

Apogon lativittatus Randall, n. sp.

Figures 1, 2; Table 1

Apogon sp. Randall, 1985:471 (Marquesas Islands).

HOLOTYPE: врвм 11665, male, $54.3 \mathrm{~mm}$, Marquesas Islands, Fatu Hiva, NE of Matahumu Point, rock and coral bottom, $6 \mathrm{~m}$, quinaldine, J. E. Randall, 18 April 1971.

PARATYPES: BPBM 11677, 4: 45.1$58.4 \mathrm{~mm}$, same locality as holotype, $6-12 \mathrm{~m}$, rotenone, J. E. Randall, D. B. Cannoy, and R. M. McNair, 19 April 1971; AMs I.39939-001, $50.2 \mathrm{~mm}$, ANSP $177853,53.1 \mathrm{~mm}$, CAs 211280 , $43.8 \mathrm{~mm}$, and FMNH 108688, $50.5 \mathrm{~mm}$, Marquesas Islands, Fatu Hiva, off point at $\mathrm{N}$ end of Hanauu Bay, $35 \mathrm{~m}$, rotenone, J. E. Randall, D. B. Cannoy, and R. M. McNair, 21 April 1971; врвм 12102, 42.8 mm, Hiva Oa,
NW side of Tepuhiaatuna Point, steep rocky slope near shore, 3-9 m, rotenone, J. E. Randall and D. B. Cannoy, 26 April 1971; врвм 11032, 5: 20.3-52.5 mm; Ua Pou, S side of Vaieho Bay off entrance to large cave, rocky shore in 0-9 $\mathrm{m}$, rotenone, J. E. Randall, D. B. Cannoy, G. S. Haywood, and J. D. Bryant, 29 April 1971; MNHN 2000-350, 2: 53.6-55.0 mm, NSMT-P 59105, $51.0 \mathrm{~mm}$, and USNM 360018, $53.3 \mathrm{~mm}$, Nuku Hiva, NW side of Sentinelle de l'Oest (off Taiohae Bay), $30.5 \mathrm{~m}$, rotenone, J. E. Randall, D. B. Cannoy, and J. D. Bryant, 16 May 1971; врвм 28069, $28.5 \mathrm{~mm}$, Line Islands, Tabuaeran (Fanning Island), about 1 mile SE of entrance to English Harbor, ocean reef slope, rubble and sand, $36.5 \mathrm{~m}$, rotenone, J. E. Randall and J. L. Earle, 4 April 1981; врвм 38526, $41.1 \mathrm{~mm}$, Eiao, about $1 / 2$ mile $\mathrm{S}$ of Vaituha Bay, boulder bottom, $15 \mathrm{~m}$, rotenone, J. L. Earle, 7 October 1998.

DIAGNosis: Dorsal-fin rays VI + I,9; analfin rays II,8; pectoral-fin rays 13 ; lateral-line scales 25 ; median predorsal scales $8-9$; gill rakers $4+12-13$; preopercular edge finely 
serrate; preopercular ridge smooth; body depth 2.65-3.0 in SL; dorsal profile of head from interorbital to dorsal-fin origin straight; interorbital space of adults not broad, the least width 5.25-5.95 in head length; first anal soft ray more than 1.5 times longer than last anal ray; caudal fin slightly forked, with broadly rounded lobes; adults red, the edges of scales dorsally on body blackish; a very broad lateral blackish stripe posteriorly on body and extending to end of caudal fin; a large, faint, dusky blotch behind eye and another at pectoral-fin base; a semicircular blackish spot just behind preopercular margin; fins translucent with light red rays; juveniles similar in color, but translucent red with a more distinct blackish band from behind eye to pectoral-fin base.

DESCRIPTION: Dorsal-fin rays VI $+\mathrm{I}$,9; anal-fin rays $I I, 8$; all dorsal and anal-fin rays branched, the last to base; pectoral-fin rays 13 , the upper two and lower one or two unbranched; pelvic-fin rays I,5; principal caudalfin rays 17 , the upper and lower unbranched; upper and lower procurrent caudal-fin rays 9, the posterior two segmented; lateral line complete, the pored scales 25 , plus 5 (4-5, usually 5) progressively smaller pored scales on caudal-fin base, the last pointed; predorsal scales 8 (8-9); scales above first lateral-line scale to origin of dorsal fin 4.5 (4.5-5.5, usually 5.5); scales above lateral line to base of middle dorsal spines 3.5; scales below lateral line to origin of anal fin $10(9-11)$; circumpeduncular scales 22 (19-23); gill rakers $4+12(4+12-13), 1+7$ developed; pseudobranchial filaments 14 (11-14); branchiostegal rays 7 ; vertebrae $10+14$; supraneural (predorsal) bones 3 .

Body depth 2.9 (2.65-3.0) in SL; body width 2.1 (1.95-2.25) in depth; head length $2.45(2.35-2.45)$ in SL; dorsal profile from interorbital to origin of dorsal fin straight; snout length 4.15 (4.05-4.2) in head; orbit diameter 3.1 (2.55-3.25) in head; interorbital space flat except for a slight concavity over a sinus on each side of median, the least bony width 5.85 (5.45-5.95) in head; caudalpeduncle depth 2.5 (2.45-2.8) in head; caudalpeduncle length 1.7 (1.55-1.8) in head.

Mouth large, the maxilla usually reaching a vertical at posterior edge of orbit, the upperjaw length 1.75 (1.7-1.9) in head; mouth slightly inferior and moderately oblique, the gape forming an angle of about $25^{\circ}$ to horizontal axis of head and body; supramaxilla absent; posterior end of maxilla fully exposed on cheek when mouth closed, the margin truncate with rounded corners; a broad band of villiform teeth in jaws, narrowing posteriorly, the innermost at front of jaws incurved and slightly enlarged; teeth in upper jaw in a maximum of about eight irregular rows, and those in lower jaw in a maximum of about six irregular rows; a symphyseal gap in teeth at front of upper jaw, its width about one-sixth pupil diameter; no obvious median gap in teeth at front of lower jaw; a V-shaped band of villiform teeth on vomer in three rows anteriorly, narrowing to one posteriorly; palatines with a band of villiform teeth in two to three irregular rows. Sides of anterior free portion of tongue nearly parallel, the front rounded. Longest gill rakers those at angle and adjacent one on lower limb, about onethird orbit diameter in adults.

Opercular spine at level of center of eye, flat, and acute, followed by broadest part of opercular flap; posterior margin of preopercle finely serrate, the number of serrae 22 (12$21)$; ventral margin of preopercle and subopercle thin and membranous; preopercular ridge smooth; no serrae on edge of posttemporal. Anterior nostril a short membranous tube, slightly higher posteriorly, at level of lower third of orbit, about one-third orbit diameter in front of bony edge of orbit; posterior nostril a large vertical slit in front of center of orbit, the internarial distance 4.2 in orbit diameter in holotype; a broad slitlike aperture at front of snout, its lower end nearly reaching base of anterior nostril; a large pore below posterior nostril; pair of mandibular pores at tip of chin of moderate size, the second and last pairs of mandibular series large; other pores of lateralis system of head small; numerous rows of small sensory papillae dorsally on head, on suborbital, preopercular flange, and extending posteriorly from orbit (those behind middle half of eye in four distinct rows).

Scales finely ctenoid; scales on nape ex- 
TABLE 1

Proportional Measurements of Type Specimens of Apogon lativittatus Expressed as Percentages of the Standard Length

\begin{tabular}{|c|c|c|c|c|c|c|c|c|c|}
\hline \multirow[b]{3}{*}{ Character } & \multirow{3}{*}{ 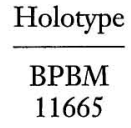 } & \multicolumn{8}{|c|}{ Paratypes } \\
\hline & & BPBM & BPBM & BPBM & ВРВM & BPBM & BPBM & BPBM & BPBM \\
\hline & & 11032 & 11032 & 12102 & 11032 & 11032 & 11677 & 11677 & \\
\hline Standard length (mm) & 54.3 & 29.2 & 31.0 & 42.8 & 49.4 & 52.5 & 53.7 & 56.8 & 58.4 \\
\hline Body depth & 34.5 & 34.9 & 33.4 & 33.8 & 35.8 & 37.5 & 37.2 & 36.7 & 37.8 \\
\hline Body width & 16.6 & 15.5 & 16.9 & 16.5 & 17.4 & 18.6 & 19.2 & 17.0 & 18.8 \\
\hline Head length & 41.0 & 41.6 & 42.0 & 42.0 & 42.6 & 41.0 & 41.7 & 41.9 & 41.5 \\
\hline Snout length & 9.9 & 10.2 & 10.3 & 10.4 & 10.1 & 9.9 & 10.1 & 10.2 & 10.3 \\
\hline Orbit diameter & 13.1 & 16.2 & 15.2 & 14.1 & 14.2 & 13.2 & 12.9 & 13.0 & 12.7 \\
\hline Interorbital width & 7.0 & 7.5 & 7.5 & 7.3 & 7.8 & 7.6 & 7.0 & 7.1 & 7.3 \\
\hline Caudal-peduncle depth & 16.2 & 14.4 & 15.5 & 16.3 & 16.2 & 16.4 & 16.9 & 15.9 & 15.6 \\
\hline Caudal-peduncle length & 24.2 & 26.4 & 26.0 & 24.2 & 26.2 & 26.1 & 24.3 & 23.4 & 24.5 \\
\hline Upper-jaw length & 23.4 & 23.6 & 22.2 & 23.5 & 23.9 & 22.8 & 23.5 & 23.2 & 24.2 \\
\hline Predorsal length & 44.3 & 44.5 & 43.5 & 44.5 & 44.9 & 44.8 & 44.7 & 44.4 & 44.6 \\
\hline Preanal length & 64.6 & 60.2 & 60.5 & 61.3 & 63.0 & 64.2 & 63.7 & 63.5 & 66.4 \\
\hline Prepelvic length & 40.3 & 36.7 & 38.4 & 38.8 & 39.2 & 40.4 & 37.5 & 38.2 & 38.8 \\
\hline First dorsal spine & 7.3 & 7.9 & 7.4 & 7.0 & 6.8 & 6.7 & 5.6 & 7.1 & 7.3 \\
\hline Second dorsal spine & 20.4 & 22.2 & 22.7 & 22.4 & 22.3 & 21.4 & 19.1 & 22.2 & 20.6 \\
\hline Third dorsal spine & 18.4 & 20.4 & 19.7 & 19.5 & 19.1 & 19.3 & 17.3 & 19.5 & 18.1 \\
\hline Spine of second dorsal fin & 15.1 & 16.9 & 16.4 & 15.7 & 14.4 & 15.3 & 13.6 & 15.8 & 14.4 \\
\hline Longest dorsal ray & 24.3 & 26.9 & 25.8 & 23.7 & 24.6 & 25.0 & 24.2 & 24.3 & 24.0 \\
\hline First anal spine & 4.1 & 5.1 & 4.9 & 4.9 & 4.5 & 5.0 & 4.1 & 5.2 & 5.1 \\
\hline Second anal spine & 14.4 & 16.1 & 15.6 & 15.4 & 14.0 & 14.4 & 13.2 & 15.3 & 13.9 \\
\hline Longest anal ray & 23.4 & 24.8 & 24.2 & 23.5 & 23.5 & 23.6 & 23.8 & 23.4 & 22.9 \\
\hline Last anal ray & 12.7 & 13.2 & 13.4 & 12.3 & 12.5 & 12.7 & 12.6 & 12.5 & 13.4 \\
\hline Caudal-fin length & 29.8 & 34.7 & 32.5 & broken & 33.9 & 30.5 & 29.9 & 30.0 & 29.5 \\
\hline Caudal concavity & 9.4 & 13.3 & 11.5 & - & 11.7 & 9.9 & 9.8 & 10.1 & 9.1 \\
\hline Pectoral-fin length & 24.4 & 26.7 & 25.8 & 25.7 & 24.6 & 24.9 & 24.2 & 25.2 & 24.7 \\
\hline Pelvic-spine length & 15.1 & 17.7 & 16.8 & 16.3 & 16.2 & 15.8 & 15.1 & 16.3 & 16.0 \\
\hline Pelvic-fin length & 25.4 & 25.5 & 24.6 & 25.7 & 25.0 & 25.0 & 24.2 & 24.7 & 25.6 \\
\hline
\end{tabular}

tending forward nearly to a vertical at rear edge of orbit; 10 scales on opercle, the largest about equal to largest scale on side of body; 10 scales along edge of preopercular ridge, preceded by a short row of scales (scales variously missing from preopercle of all specimens); first scales anterior to first dorsal fin not median, but overlapping from side; first median predorsal scale sometimes notched posteriorly (median predorsal scales difficult to count on some specimens due to overlapping scales in median line); four median dorsal scales between dorsal fins, smaller posteriorly, the posterior two notched, the last extending onto front of spine of second dorsal fin; no scales on fins except small scales on base of caudal fin; a midventral scaly process of three large scales (the most anterior often missing), extending posteriorly from between bases of pelvic fins, its length about half length of pelvic spines.

Origin of first dorsal fin over base of third lateral-line scale, the predorsal distance 2.25 (2.2-2.3) in SL; spines of fins strong, especially the second; first dorsal spine short, 5.55 (5.25-7.45) in head; second dorsal spine longest, $2.0(1.85-2.2)$ in head; third dorsal spine 2.2 (2.05-2.4) in head; spine of second dorsal fin $2.7(2.45-2.95)$ in head; first dorsal soft ray usually longest (the second subequal), 1.7 $(1.55-1.75)$ in head; origin of anal fin below origin of second dorsal fin, the preanal distance 1.55 (1.5-1.65) in head; first anal spine very short, $10.0(8.05-10.0)$ in head; second anal spine $2.85(2.6-3.15)$ in head; first anal soft ray usually longest $1.75(1.7-1.8)$ in head; 
last anal soft ray $3.2(3.1-3.4)$ in head; caudal fin slightly forked with broadly rounded lobes, its length 3.35 (2.9-3.4) in SL, the caudal concavity $4.35(3.15-4.55)$ in head; third or fourth pectoral ray usually longest, 1.7 (1.55-1.7) in head; origin of pelvic fins distinctly anterior to base of pectoral fins, the prepelvic distance 2.5 (2.5-2.7) in SL; pelvic spine 2.7 (2.35-2.75) in head; first pelvic soft ray longest, $1.6(1.6-1.7)$ in head.

Color of holotype in alcohol: pale orangish brown with a midlateral blackish stripe commencing below front of second dorsal fin and broadening posteriorly to nearly threefourths depth of caudal peduncle at caudal-fin base, then narrowing as it passes to end of caudal fin; a narrow, less distinct, middorsal blackish stripe (from dark edges on scales) from posterior nape along back at base of dorsal fins, and ending posteriorly at caudalfin base; some dusky pigment in a large blotch behind eye; a large area at base of pectoral fin faintly dusky; occiput dark reddish; fins pale yellowish; peritoneum and digestive tract slightly dusky.

Color of holotype when fresh: red, the edges of scales dorsally on body blackish, this pigmentation most intense on first three rows of scales, thus seeming like a dark dorsal stripe; a very broad blackish stripe posteriorly on side of body, commencing below origin of second dorsal fin, and extending to posterior margin of caudal fin; a large, faint, dusky blotch behind eye, and another at pectoral-fin base; a semicircular blackish spot just behind preopercular margin; fins translucent with light red rays; iris blackish with an outer rim of dusky yellow.

Juveniles translucent red with markings as above, except dark pigmentation of scales dorsally on body less developed, but oblique band from eye to pectoral-fin base more distinct; a faint blackish stripe present on lower side of abdomen from axil of pelvic fin to above origin of anal fin (where more prominent), continuing above and into base of anal fin, and extending out onto last five rays and membranes; iris pale yellow.

eтумоlogy: This species is named Apogon lativittatus from the Latin latus meaning broad, and vitta for stripe or band, in specific reference to the broad blackish midlateral

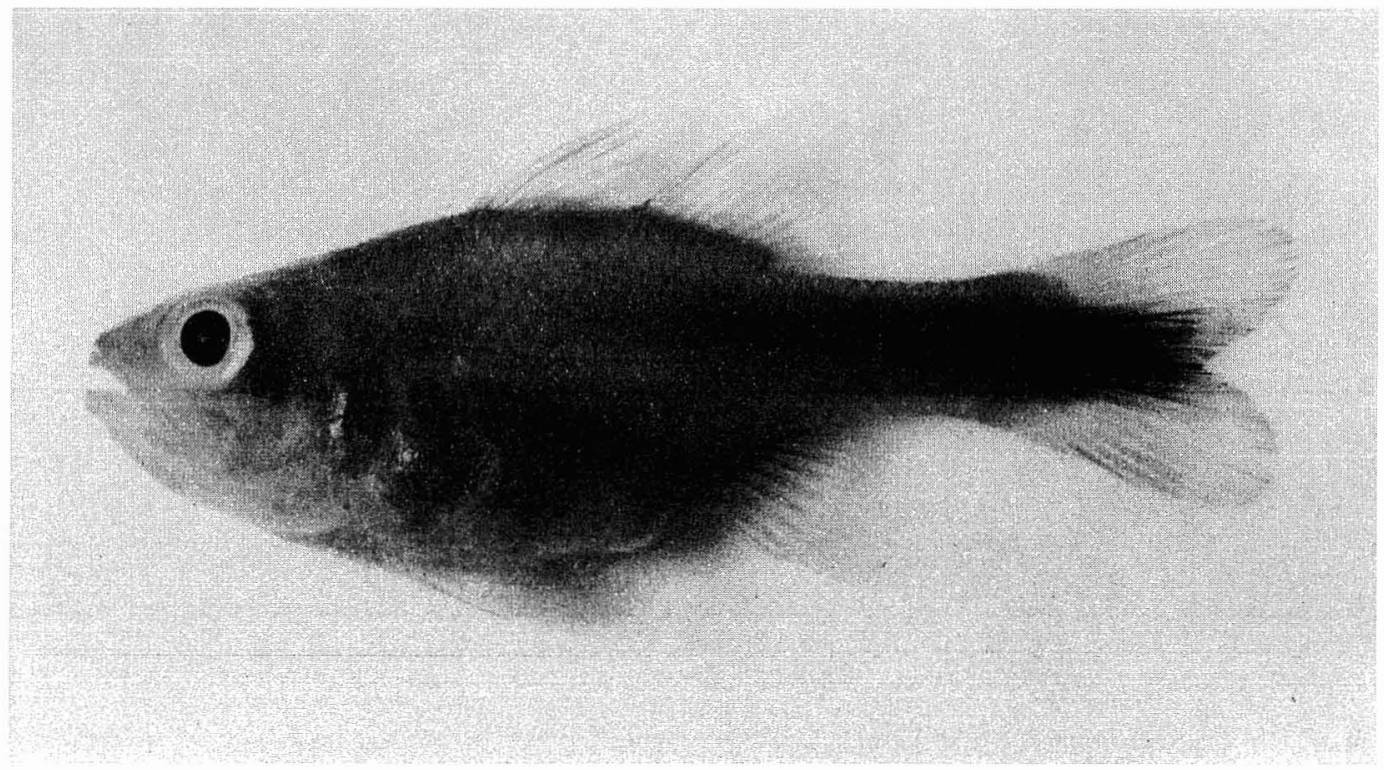

Figure 2. Paratype of Apogon lativittatus, врвм 38526, $41.1 \mathrm{~mm}$, Eiao, Marquesas Islands. 
stripe on the body and caudal fin that is wider on the average than that of $A$. semiornatus.

REMARKS: When first collected in the Marquesas, the adults of this species were identified as Apogon sp., and the juveniles as $A$. semiornatus Peters. When it was determined that they represent the same species, a comparison was made with material of 16 lots of A. semiornatus in the Bishop Museum from the Red Sea, Indian Ocean, and East Indies. The most obvious difference is size. The largest of 33 specimens of $A$. semiornatus, врвм 21386 from the Gulf of Oman, measures $47.2 \mathrm{~mm} \mathrm{SL}$. Of the 21 type specimens of $A$. lativittatus, 13 range from 49.4 to $58.4 \mathrm{~mm}$ SL. The large adults of $A$. lativittatus are opaque red in life, and the oblique black band from the eye to pectoral-fin base is nearly lacking, hence another reason for regarding them as a different species from the smaller specimens that resemble $A$. semiornatus.

Apogon lativittatus is also distinct from A. semiornatus in the much straighter dorsal profile of the head. Less obvious but apparent through measurement of available specimens is the greater average body depth of $A$. lativittatus. The depth of 21 type specimens, $29.2-58.4 \mathrm{~mm}$, is $33.0-38.8 \%$ SL (mean $35.7 \%$ ), compared with 30.7-36.4\% SL (mean $33.3 \%$ ) for $21 \mathrm{~A}$. semiornatus (juveniles are more slender, in general; no $A$. semiornatus less than $27 \mathrm{~mm}$ were measured). Meristic data revealed a difference in the number of pectoral rays, 13 for all of the $A$. lativittatus, 12 for all but two of $A$. semiornatus that have 13 rays (one of these with 12 on the other side). In addition, $A$. lativittatus has $4.5-5.5$ scales in an oblique row above the first lateral-line scale to the origin of the first dorsal fin, compared with 3-3.5 scales for $A$. semiornatus, and the number of circumpeduncular scales is greater in A. lativittatus (19-23, compared with $15-17$ for $A$. semiornatus). Also, A. lativittatus usually has 5 small pored scales in the lateral line posterior to the caudal-fin base (when all present), whereas $A$. semiornatus usually has 4 .

Only one specimen labeled Apogon semiornatus was found in the Bishop Museum collection that was obtained from an island in
Oceania other than the Marquesas: врвм 28069, $28.5 \mathrm{~mm}$ SL, from Tabuaeran (Fanning Island) in the Line Islands. It has 13 pectoral rays on both sides, 4.5 scales above the lateral line, and 19 circumpeduncular scales. It is reidentified as $A$. lativittatus and listed above as a paratype. Three other species of fishes initially believed to be endemic to the Marquesas were later found in the Line Islands: Cbaetodon declivis Randall, Mulloidichtbys mimicus Randall \& Guézé, and Pervagor marginalis Hutchins.

No specimens of Apogon semiornatus were recorded for the islands of Micronesia by Myers (1999), and none is present in the large fish collections from islands of Oceania in the California Academy of Sciences (David Catania, pers. comm.) or the National Museum of Natural History (David G. Smith, pers. comm.).

Like Apogon semiornatus, $A$. lativittatus is a secretive species. Its presence was revealed in the sea only after the use of rotenone. Specimens were usually found associated with rocky bottom along exposed shores. The depth of capture ranged from less than 9 (one lot from 0 to 9 and one from 3 to $9 \mathrm{~m}$ ) to $36.5 \mathrm{~m}$.

\section{Apogon relativus Randall, $\mathrm{n} . \mathrm{sp}$.}

Figure 3; Table 2

?Amia aroubiensis (non Hombron \& Jacquinot) Seale, 1906:33; Fowler, 1928:157 (Nuku Hiva).

Apogon angustata (non Smith \& Radcliffe) Herre, 1936:124 (Nuku Hiva).

Amia novemfasciata (non Cuvier) Fowler, 1938:68 (Nuku Hiva).

Apogon sp. Randall, 1985:471 (Marquesas Islands).

HоLотуре: врвм 11699, male, $71.8 \mathrm{~mm}$, Marquesas Islands, Fatu Hiva, NE of Matahumu Point, rocky bottom, 6-12 m, rotenone, J. E. Randall, D. B. Cannoy, and R. M. McNair, 19 April 1971.

PARATYPES: FMNH. 21982, $64.4 \mathrm{~mm}$, Marquesas Islands, Nuku Hiva, Crane Pacific Expedition, 7 February 1929; ANSP 82407, $52.3 \mathrm{~mm}$, Nuku Hiva, Vanderbilt South Pacific Expedition, 20 March 1937; USNM 


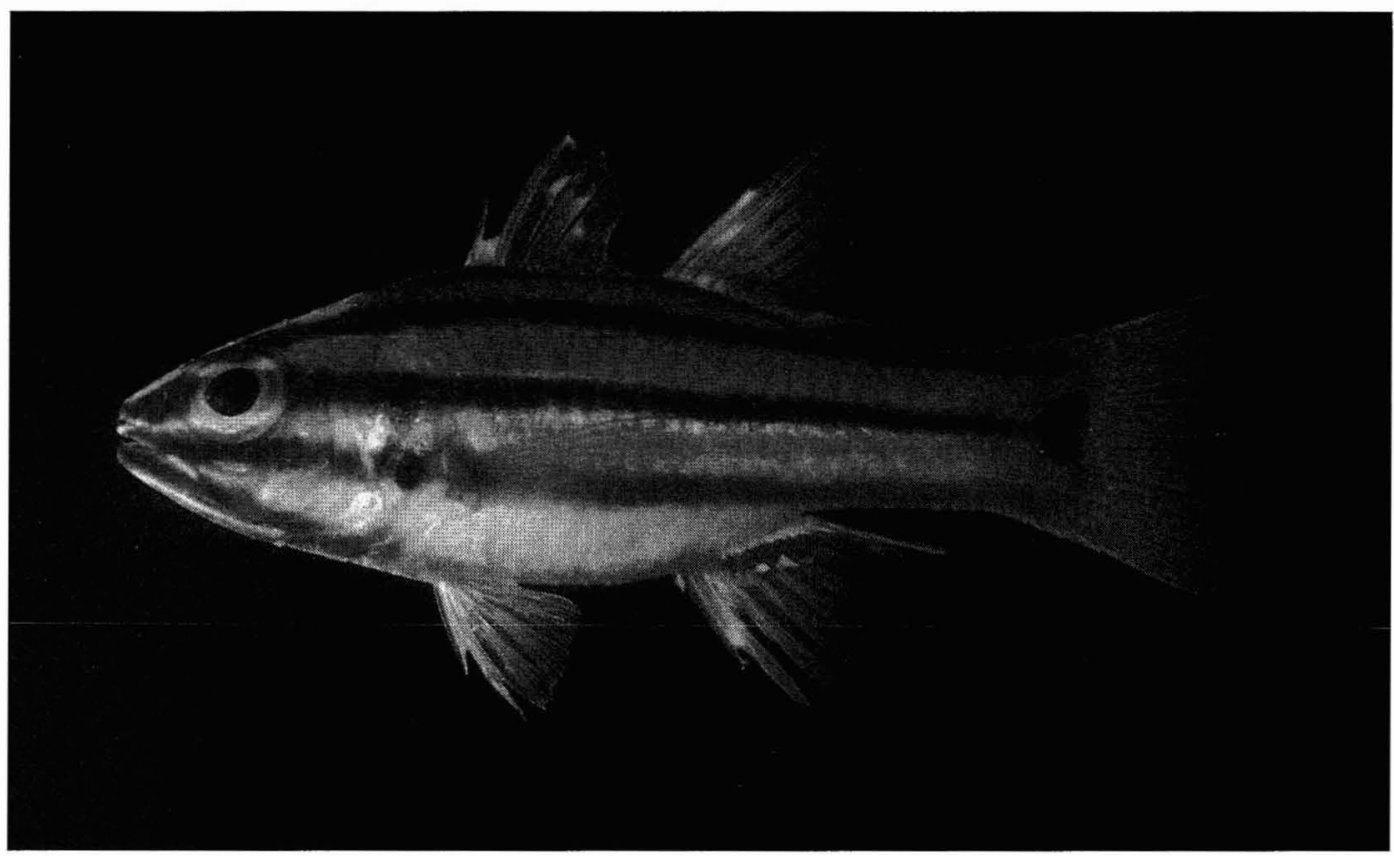

Figure 3. Holotype of Apogon relativus, врвм 11699, $71.8 \mathrm{~mm}$, Fatu Hiva, Marquesas Islands.

359800, 11: 21.3-75.5 mm, Nuku Hiva, Taipi Vai, Haka Puuae, rotenone, D. W. Strasburg, Charles H. Gilbert Cruise 30, 9 September 1956; AMs I.39937-001, 12: 22.2$66.5 \mathrm{~mm}$, Nuku Hiva, Taiohae Bay, coral reef, $0.3-3 \mathrm{~m}$, rotenone, crew of Charles $H$. Gilbert, Cruise 54, 11 October 1961; CAS 211005, 14: $21.6-65.8 \mathrm{~mm}$, same data as preceding; врвм 38690, 4: 69.2-73.8 mm, same data as holotype; врвм 11030, 9: 23.9$71.3 \mathrm{~mm}$, Ua Pou, S side of Vaeho Bay off entrance to large cave, rocky shore in 0-9 $\mathrm{m}$, rotenone, J. E. Randall, D. B. Cannoy, G. S. Haywood, and J. D. Bryant, 29 April 1971; MNHN 2000-190, 6: 57.0-68.8 mm, Nuku Hiva, Taiohae Bay, $W$ side near head of bay, 1-2 m, rotenone, J. E. Randall and J. D. Bryant, 10 May 1971; NSMT-P 59101, $52.0 \mathrm{~mm}$, Nuku Hiva, Taiohae Bay, rocky shore to nearby zone of large heads of Porites, 0-2 m, rotenone, J. E. and H. A. Randall, 19 Mау 1971; врвм 38518, 2: 34.0-36.7 mm, Eiao, about one-half mile $\mathrm{S}$ of Vaituha Bay, boulder bottom, $7 \mathrm{~m}$, rotenone, J. E. Randall and J. L. Earle, 7 October 1998.
DIAGNosis: Dorsal-fin rays $\mathrm{VII}+\mathrm{I}, 9$; anal-fin rays II,8; pectoral-fin rays 14; lateralline scales 25; median predorsal scales 4; gill rakers 5-6+14-16; preopercular edge serrate; preopercular ridge smooth; body depth 2.85-3.4 in SL; bony interorbital width 4.054.8 in head length; last anal soft ray nearly as long as first ray in large adults, and nearly twice as long as penultimate ray; caudal fin slightly forked, with broadly rounded lobes; pale greenish gray with five dark stripes about half as broad as pale interspaces; midlateral dark stripe ending in a vertically oval black spot about twice as high as greatest width of stripe; fins light red, the second dorsal and anal fins with a dark stripe near base that extends out to ends of last two rays; peritoneum and digestive tract pale.

DESCRIPTION: Dorsal-fin rays VII + I,9; anal-fin rays II,8; all dorsal and anal-fin rays branched, the last to base; pectoral-fin rays 14 , the upper two and lowermost unbranched; pelvic-fin rays I,5; principal caudalfin rays 17 , the upper and lower unbranched; upper and lower procurrent caudal-fin rays 
TABLE 2

Proportional Measurements of Type Specimens of Apogon relativus

Expressed as Percentages of the Standard Length

\begin{tabular}{|c|c|c|c|c|c|c|c|c|c|}
\hline \multirow[b]{3}{*}{ Character } & \multirow{3}{*}{$\begin{array}{c}\text { Holotype } \\
\text { BPBM } \\
11699\end{array}$} & \multicolumn{8}{|c|}{ Paratypes } \\
\hline & & BPBM & ВРВM & ВРВM & BPBM & BPBM & BPBM & ВРВM & ВРBM \\
\hline & & 11030 & 38518 & 11030 & 11030 & 11030 & 11030 & 38690 & 38690 \\
\hline Standard length (mm) & 71.8 & 23.9 & 36.7 & 41.6 & 45.0 & 55.4 & 67.4 & 70.2 & 73.8 \\
\hline Body depth & 34.7 & 29.5 & 30.0 & 31.7 & 32.9 & 34.0 & 33.3 & 34.2 & 35.0 \\
\hline Body width & 17.7 & 16.5 & 17.2 & 15.0 & 15.5 & 16.7 & 16.6 & 16.8 & 17.7 \\
\hline Head length & 39.9 & 37.7 & 39.6 & 39.4 & 39.7 & 39.4 & 38.1 & 38.0 & 38.0 \\
\hline Snout length & 11.1 & 10.0 & 9.5 & 10.7 & 10.0 & 9.4 & 9.7 & 9.8 & 8.0 \\
\hline Orbit diameter & 12.6 & 14.2 & 14.1 & 14.5 & 13.5 & 13.5 & 12.7 & 12.6 & 12.3 \\
\hline Interorbital width & 8.3 & 9.3 & 8.8 & 8.5 & 8.7 & 8.3 & 8.1 & 8.1 & 8.0 \\
\hline Caudal-peduncle depth & 19.2 & 16.8 & 16.8 & 17.0 & 17.7 & 17.9 & 19.3 & 19.3 & 18.7 \\
\hline Caudal-peduncle length & 24.8 & 25.6 & 26.4 & 25.9 & 24.5 & 25.0 & 26.1 & 24.7 & 24.8 \\
\hline Upper-jaw length & 20.0 & 19.5 & 20.5 & 20.3 & 20.4 & 20.3 & 20.0 & 19.6 & 20.2 \\
\hline Predorsal length & 41.7 & 38.4 & 39.8 & 41.6 & 40.7 & 41.8 & 40.6 & 40.3 & 40.6 \\
\hline Preanal length & 60.9 & 59.0 & 59.2 & 60.5 & 60.0 & 61.6 & 62.0 & 62.2 & 61.7 \\
\hline Prepelvic length & 37.2 & 35.7 & 35.4 & 34.5 & 37.8 & 36.7 & 37.4 & 36.8 & 36.3 \\
\hline First dorsal spine & 4.5 & 5.3 & 5.3 & broken & 4.5 & 4.1 & 4.4 & 4.2 & 4.3 \\
\hline Second dorsal spine & 10.4 & 12.6 & 12.2 & 12.1 & 11.1 & 10.3 & 10.2 & 10.1 & 10.6 \\
\hline Third dorsal spine & 20.9 & 18.9 & 21.8 & 21.7 & 20.9 & 21.8 & 22.0 & 20.2 & 22.5 \\
\hline Spine of second dorsal fin & 17.8 & 16.5 & 17.7 & 18.8 & 18.3 & 17.7 & 18.1 & 17.6 & 17.8 \\
\hline Longest dorsal ray & 27.2 & 23.9 & 28.6 & 29.0 & 28.5 & 28.8 & 27.5 & 28.9 & 29.0 \\
\hline First anal spine & 4.7 & 5.1 & 4.9 & 4.5 & 4.4 & 5.2 & 4.5 & 5.1 & 4.4 \\
\hline Second anal spine & 15.9 & 14.2 & 14.3 & 15.7 & 15.5 & 15.9 & 15.1 & 15.7 & 15.5 \\
\hline First anal ray & 22.2 & 23.3 & 24.5 & 24.8 & 24.9 & 25.0 & 23.1 & 24.4 & 24.9 \\
\hline Last anal soft ray & 21.7 & 13.0 & 16.9 & 19.3 & 18.0 & 19.8 & 21.8 & 22.7 & 23.5 \\
\hline Caudal-fin length & 31.2 & 32.2 & 32.8 & 34.2 & 33.6 & 33.5 & 32.5 & 32.6 & 31.7 \\
\hline Caudal concavity & 9.6 & 10.6 & 10.9 & 11.2 & 11.0 & 11.1 & 10.8 & 10.2 & 10.1 \\
\hline Pectoral-fin length & 23.8 & 22.8 & 23.9 & 23.8 & 24.2 & 23.8 & 22.7 & 24.4 & 23.1 \\
\hline Pelvic-spine length & 14.9 & 16.6 & 16.1 & 16.2 & 15.8 & 15.8 & 14.7 & 14.9 & 15.1 \\
\hline Pelvic-fin length & 26.5 & 22.3 & 24.5 & 24.3 & 23.5 & 24.9 & 24.4 & 24.9 & 24.7 \\
\hline
\end{tabular}

8 , the posterior two segmented; lateral line complete, the pored scales 25 (plus 3 progressively smaller scales on caudal-fin base, the last pointed); predorsal scales 4 , the fourth deeply notched posteriorly (its medial part nearly covered by the third), the third scale slightly notched; scales above lateral line to orgin of dorsal fin 2; scales below lateral line to origin of anal fin 5.5; circumpeduncular scales 14; gill rakers $5+14(5-6+$ 14-16); developed gill rakers $3+12(2-3+$ 11-14); pseudobranchial filaments $22(12-21)$; branchiostegal rays 7 ; vertebrae $10+14$; supraneural (predorsal) bones 3 .

Body depth 2.9 (2.85-3.4) in SL, the depth decreasing relative to the SL with growth; body width 1.95 (1.75-2.1) in depth; head length $2.5(2.5-2.65)$ in SL; snout length 3.15
(2.65-3.1) in head; orbit diameter 3.15 (2.653.1 ) in head; interorbital space broad and very slightly convex, the least bony width 4.8 (4.05-4.75) in head; caudal-peduncle depth $2.1(1.95-2.35)$ in head; caudal-peduncle length $1.6(1.45-1.6)$ in head.

Mouth large, the maxilla extending posterior to a vertical at posterior edge of pupil, the upper-jaw length $2.0(1.85-1.95)$ in head; mouth terminal to slightly inferior, and moderately oblique, the gape forming an angle of about $25^{\circ}$ to horizontal axis of head and body; supramaxilla absent; posterior edge of maxilla truncate to very slightly concave with strongly rounded corners; a broad band of villiform teeth in jaws, narrowing posteriorly, none enlarged, those in upper jaw in a maximum of about eight irregular rows, and 
those in lower jaw in a maximum of about six irregular rows; a symphyseal gap in teeth at front of upper jaw, its width about onethird pupil diameter; no obvious gap in teeth at front of lower jaw; a narrow band of villiform teeth on vomer and palatines in two irregular rows, those on vomer in a $\mathrm{V}$ shape. Sides of free part of tongue parallel, the front rounded. First gill raker on lower limb next to raker at angle longest, one-half orbit diameter in holotype.

Opercular spine at level of center of eye, flat, and acute, followed by pointed flap of opercular membrane; free margin of preopercle finely serrate except about anterior half of ventral edge, the largest serrae on the broadly rounded corner; preopercular ridge smooth (cteni of scales overlapping edge of ridge may make it seem very finely serrate); edge of suborbital smooth; ventroposterior edge of posttemporal with a few small serrae (five on one side of holotype, three on other). Anterior nostril a short membranous tube, slightly higher posteriorly, at level of lower edge of pupil, about one-third orbit diameter in front of edge of orbit; posterior nostril an elliptical opening dorsoposterior to anterior nostril, the internarial distance 4.5 in orbit diameter in holotype; a broad slitlike aperture below internarial space and nearly parallel to it, and three broad slitlike openings directed ventrally on lower edge of snout; other pores of lateralis system of head very small except for moderately large anterior pair of mandibular pores.

Scales finely ctenoid; scales on nape extending forward to above upper end of preopercular margin; scales on preopercle in three oblique rows, the third row consisting of three broadly overlapped small scales at edge of rounded corner; opercle with nine scales, two of which are as large as or slightly larger than largest scales of body; two notched median scales anterior to dorsal fin, the anterior almost completely overlapping the posterior; no scales on fins except small scales on base of caudal fin; a midventral scaly process of two large scales, flanked by two small scales, extending posteriorly from between bases of pelvic fins, its length about half length of pelvic spines.
Origin of first dorsal fin over base of third lateral-line scale, the predorsal distance 2.4 (2.4-2.6) in SL; spines of fins strong; first dorsal spine very short, 8.8 (7.1-9.6) in head; second dorsal spine $3.85(3.0-3.85)$ in head; third dorsal spine longest and the most stout, $1.9(1.7-2.0)$ in head; spine of second dorsal fin 2.25 (2.1-2.3) in head; first dorsal soft ray longest, $1.45(1.3-1.6)$ in head; origin of anal fin below base of second or third dorsal soft rays, the preanal distance $1.65(1.6-1.7)$ in head; first anal spine very short, 8.5 (7.49.05) in head; second anal spine 2.5 (2.42.75) in head; first anal soft ray usually longest (last ray may be as long on large adults), 1.7 (1.5-1.65) in head; last anal soft ray increasing relatively to other rays with growth, its length nearly twice length of penultimate ray in large adults, 1.85 (1.6-2.9) in head; caudal fin slightly forked with broadly rounded lobes, its length $3.3(2.9-3.45)$ in SL, the caudal concavity $4.3(3.5-4.5)$ in head; third or fourth pectoral rays longest, $1.65(1.55-1.7)$ in head; origin of pelvic fins slightly anterior to base of pectoral fins, the prepelvic distance 2.7 (2.65-2.9) in SL; pelvic spine $2.7(2.25-2.6)$ in head; first pelvic soft ray longest, $1.5(1.5-1.7)$ in head.

Color of holotype in alcohol: pale orangish brown with four dark brown stripes, the first narrow, middorsal, beginning on interorbital, bifurcating at origin of first dorsal fin, and passing on each side at base of dorsal fins; second stripe from dorsally on snout, passing through upper part of eye, and continuing above anterior part of lateral line to upper caudal-fin base; third stripe from behind center of eye, ending at midbase of caudal fin; fourth stripe from lower edge of eye to pectoral-fin base, reappearing at axil of pectoral fin, and continuing to lower caudal-fin base; stripes about half as broad as pale interspaces; a vertically oval black spot on midbase of caudal fin, separated by a narrow pale space from posterior end of midlateral dark stripe, the height of spot twice width of this stripe at its widest place; fins pale yellowish, the second dorsal and anal fins with a dusky stripe near base that extends out onto tip of last ray. Peritoneum and digestive tract pale.

Color of holotype when fresh: pale green- 
ish gray with dark brown stripes as described above, except the midlateral stripe continues brownish red through eye to front of snout, the dark orangish brown fourth stripe extends as brownish red anteriorly on head to side of upper lip, and a fifth brownish red stripe (not apparent in preservative) extends from tip of chin across lower part of head, ventrally on chest and abdomen, into basal part of anal fin, and ending distally on last ray; midlateral dark stripe edged below (and slightly above) with yellow-green iridescence; pale areas of cheek and opercle also with iridescence; a black spot within fourth dark stripe posteriorly on opercle; first dorsal fin with light red spines and translucent membranes that are pale red except for greenish on central and basal part of last four membranes; second dorsal fin with a red band near base that rises to tip of last ray, the fin below band greenish white; fin rays pale greenish, edged in pink, the membranes translucent pale red, suffused with pale greenish; anal fin similar to second dorsal, but with greenish white blotches at outer edge of red band, one on each of middle three membranes; caudal fin with translucent light red membranes and pink-edged pale greenish rays; paired fins translucent pale red with pink rays, the pink concentrated on edges.

Juveniles are much like adults in color pattern except the basicaudal spot is smaller and more round.

etymology: This species is named $A p o-$ gon relativus, from the Latin for related to, or akin to, in reference to its similarity to $A$. angustatus (Smith \& Radcliffe), a common, wide-ranging species in the Indo-Pacific, but not found in the Marquesas.

remarks: Apogon relativus occurs throughout the Marquesas Islands, where it is the most common species of cardinalfish in shallow water. It is associated with rocky substratum, both in sheltered bays and along exposed shores, and is usually seen in aggregations.

Seale (1906) and Fowler (1928) reported a specimen of Amia aroubiensis from Nuku Hiva that was deposited in the Bishop Museum. Apogon aroubiensis Hombron \& Jacquinot was described from a single specimen from Ma- laysia that is no longer extant. Randall and Lachner (1986) explained that no specimens have been found that match the description and illustration of this nominal species of Apogon. The cardinalfish that most authors have misidentified as $A$. aroubiensis is now A. nigrofasciatus Lachner. Seale's Marquesan specimen of Amia aroubiensis was not found at the Bishop Museum, nor at the Academy of Natural Sciences of Philadelphia where many Bishop Museum specimens were transferred; however, there is little doubt that it was Apogon relativus because this is the only apogonid with dark stripes similar to $A$. nigrofasciatus that occurs in the Marquesas.

Herre (1936) listed two specimens of Apogon angustatus, 64 and $79 \mathrm{~mm}$ SL, from Nuku Hiva that were deposited in the Field $\mathrm{Mu}$ seum of Natural History. The 79-mm specimen could not be found, but the 64-mm one (FMNH 21982) was sent on loan and reidentified as $A$. relativus. Similarly, Fowler (1938) reported one specimen as Amia novemfasciatus from Nuku Hiva (ANSP 82407, $52.3 \mathrm{~mm}$ ) that proved to be $A$. relativus. These two specimens are in good condition and are designated above as paratypes.

Apogon relativus is similar in color to $A$. angustatus (Smith \& Radcliffe), which has the same pattern of five dark stripes on the head and body and a black spot at the base of the caudal fin; however, the stripes are generally broader in angustatus, usually about as wide as the pale interspaces. The basicaudal black spot of angustatus is round or horizontally oval instead of vertically oval, and it is not of greater diameter than the width of the broadest stripe. No meristic differences were noted to separate the two species, but there are differences in proportions. The eye is slightly larger in angustatus when specimens the same size are compared, and the interorbital space is clearly narrower. The interorbital width of 20 specimens of $A$. angustatus, $23.7-79.3 \mathrm{~mm} \mathrm{SL}$, varied from 5.0 to 5.95 in the head length, compared with 4.05-4.8 for $A$. relativus. In addition, the last anal ray is longer in relativus when specimens of the same size are compared, and the caudal fin is usually longer.

There is a difference in the depth at which 


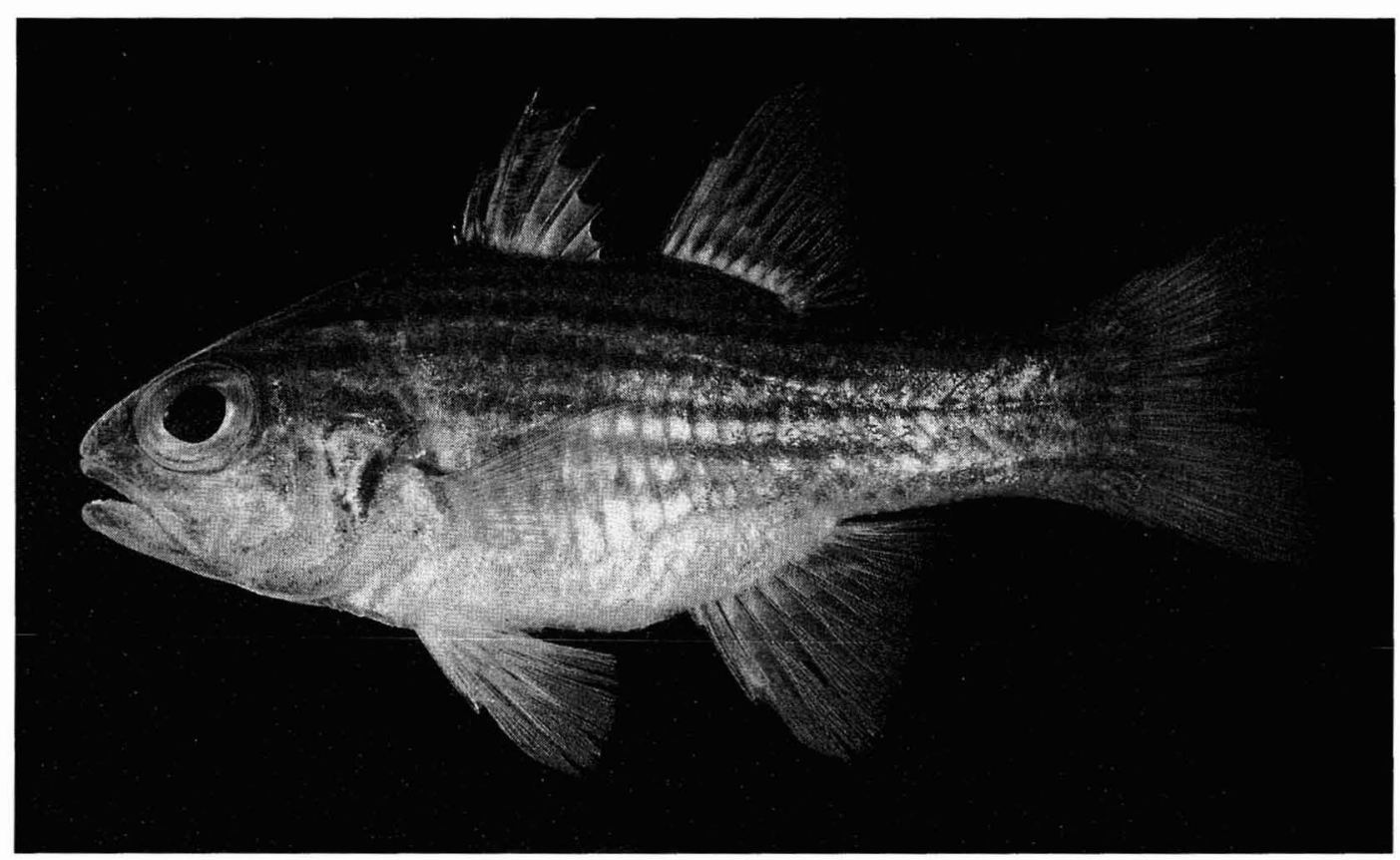

Figure 4. Holotype of Apogon sinus, врвм 12117, $80.5 \mathrm{~mm}$, Hiva Oa, Marquesas Islands.

the two species are generally found. All of the type specimens of Apogon relativus were collected in less than $9 \mathrm{~m}$. Allen (1997:102) reported Apogon angustatus as occurring "usually below 10-15 $\mathrm{m}$ depth." Of 20 lots of this species at the Bishop Museum, three were taken in $8-11 \mathrm{~m}, 11$ in $15-27 \mathrm{~m}$, and six in 30-40 m. Eichler and Myers (1997:126) gave the maximum depth as $65 \mathrm{~m}$.

Apogon sinus Randall, n. sp.

Figure 4; Table 3

Apogon sp. Randall, 1985:471 (Marquesas Islands).

HOLOTYPE: вРвм 12117, female, 80.5 $\mathrm{mm}$, Marquesas Islands, Hiva $\mathrm{Oa}$, head of Tahauka Bay on $\mathrm{W}$ side, rocky shore and adjacent black sand, 0-1 m, rotenone, J. E. and H. A. Randall, A. Haywood, and J. D. Bryant, 25 April 1971.

PARATYPES: BPBM 10356, 2: 81.5-84.9 $\mathrm{mm}$, Marquesas Islands, Nuku Hiva, Anaho Bay, small tide pool, rotenone, J. E. King, Hugh M. Smith Cruise 31, 27 November
1955; вРвм 38692, 9: 40.4-84.9 mm, АмS I.39938-001, 2: $46.1-58.4 \mathrm{~mm}$, ANSP 177850, 2: $\quad 51.0-56.4 \mathrm{~mm}$, CAS 211006, 2: 43.5$56.3 \mathrm{~mm}$, FMNH 108659 , 2: $50.2-56.5 \mathrm{~mm}$, MNHN 2000-191, 2: 59.2-70.9 mm, NSMT-P 59102, 2: 42.7-60.7 mm, USNM 359801, 2: 51.4-67.6 mm, all with same data as holotуре; врвм 12811, $69.8 \mathrm{~mm}$, Nuku Hiva, Taiohae Bay, E side at head of bay, rocky shore to nearby large heads of Porites, 0$2.5 \mathrm{~m}$, rotenone, J. E. and H. A. Randall, 19 May 1971.

DIAGNosis: Dorsal-fin rays $\mathrm{VII}+\mathrm{I}, 9$; anal-fin rays II,8; pectoral-fin rays 14; lateralline scales 25; median predorsal scales 4; gill rakers $4-5+12-13$; preopercular edge serrate, preopercular ridge smooth; body depth 2.6-2.9 in SL; interorbital space broad, the least bony width $4.2-4.45$ in head length; last anal ray less than two-thirds length of first anal ray; caudal fin slightly forked, with broadly rounded lobes; iridescent pink with seven narrow, reddish brown stripes, the upper five extending forward onto dorsal half of head; a short submarginal black bar on oper- 
culum anterior to pectoral-fin base; digestive tract black.

DESCRIPTION: Dorsal-fin rays VII + I,9; anal-fin rays II,8; all dorsal and anal fin rays branched, the last to base; pectoral-fin rays 14 , the upper two and lowermost unbranched; pelvic-fin rays I,5; principal caudalfin rays 17 , the upper and lower unbranched; upper and lower procurrent caudal-fin rays 8 , the posterior two segmented; lateral line complete, the pored scales 25 (plus 3 progressively smaller scales on caudal-fin base, the last pointed); predorsal scales 4, the fourth deeply notched posteriorly (its medial part nearly covered by the third); third predorsal scale slightly notched; scales above lateral line to origin of dorsal fin 2 (not counting most posterior median predorsal scale); scales below lateral line to origin of anal fin 5.5; circumpeduncular scales 14; gill rakers $5+14$ (5-6+14-16), $2+10$ developed; pseudobranchial filaments 22 (12-21); branchiostegal rays 7; vertebrae $10+14$; supraneural (predorsal) bones 3 .

Body depth 2.65 (2.6-2.9) in SL; body width 2.2 (2.05-2.25) in depth; head length 2.6 (2.4-2.65) in SL, decreasing relative to SL with growth; snout length $3.9(3.75-4.15)$ in head; orbit diameter $3.1(2.8-3.2)$ in head; interorbital space very slightly convex, the least bony width $4.35(4.2-4.45)$ in head; caudal-peduncle depth $2.0(2.0-2.45)$ in head; caudal-peduncle length $1.6(1.5-1.6)$ in head.

Mouth large, the maxilla extending beyond a vertical at posterior edge of pupil, the upper-jaw length $1.95(1.9-2.0)$ in head;

TABLE 3

Proportional Measurements of Type Specimens of Apogon sinus

Expressed as Percentages of the Standard Length

\begin{tabular}{|c|c|c|c|c|c|c|c|c|c|}
\hline \multirow[b]{2}{*}{ Character } & \multirow{2}{*}{$\begin{array}{c}\text { Holotype } \\
\text { BPBM } \\
12117\end{array}$} & \multicolumn{8}{|c|}{ Paratypes } \\
\hline & & $\begin{array}{c}\text { BPBM } \\
38692\end{array}$ & $\begin{array}{c}\text { ВРВM } \\
38692\end{array}$ & $\begin{array}{c}\text { BРBM } \\
38692\end{array}$ & $\begin{array}{c}\text { BPBM } \\
38692\end{array}$ & $\begin{array}{c}\text { ВРВM } \\
38692\end{array}$ & $\begin{array}{c}\text { BPBM } \\
38692\end{array}$ & $\begin{array}{c}\text { BPBM } \\
38692\end{array}$ & $\begin{array}{c}\text { BPBM } \\
38692\end{array}$ \\
\hline Standard length (mm) & 80.5 & 40.4 & 45.7 & 54.1 & 56.0 & 62.5 & 68.9 & 72.7 & 84.9 \\
\hline Body depth & 37.5 & 34.5 & 35.9 & 37.0 & 37.4 & 38.4 & 36.5 & 39.7 & 37.3 \\
\hline Body width & 17.1 & 15.4 & 17.3 & 16.6 & 17.1 & 17.6 & 16.1 & 17.0 & 18.0 \\
\hline Head length & 38.4 & 41.5 & 40.0 & 39.2 & 39.4 & 39.2 & 38.7 & 38.9 & 37.7 \\
\hline Snout length & 9.8 & 10.0 & 10.5 & 10.1 & 10.5 & 9.8 & 10.1 & 9.9 & 9.8 \\
\hline Orbit diameter & 12.5 & 14.8 & 14.3 & 13.8 & 13.9 & 13.0 & 12.7 & 12.6 & 11.8 \\
\hline Interorbital width & 8.8 & 9.3 & 9.2 & 9.2 & 8.9 & 8.9 & 8.9 & 9.2 & 8.6 \\
\hline Caudal-peduncle depth & 11.1 & 12.6 & 13.0 & 12.4 & 12.8 & 11.5 & 11.1 & 10.9 & 11.1 \\
\hline Caudal-peduncle length & 19.0 & 17.0 & 17.7 & 18.4 & 17.8 & 18.6 & 18.8 & 19.2 & 18.9 \\
\hline Upper-jaw length & 19.6 & 20.5 & 20.8 & 20.4 & 20.6 & 19.7 & 19.9 & 20.6 & 19.2 \\
\hline Predorsal length & 42.8 & 42.2 & 42.6 & 41.8 & 41.9 & 42.1 & 41.3 & 41.8 & 42.3 \\
\hline Preanal length & 62.8 & 62.1 & 61.0 & 60.8 & 61.6 & 60.3 & 62.3 & 61.4 & 61.8 \\
\hline Prepelvic length & 37.8 & 37.5 & 38.4 & 37.5 & 37.4 & 36.8 & 37.7 & 36.5 & 36.4 \\
\hline First dorsal spine & 4.3 & 5.0 & 4.9 & 4.7 & 4.1 & 4.8 & 4.9 & 4.8 & 5.1 \\
\hline Second dorsal spine & 11.4 & 13.6 & 13.7 & aberrant & 13.2 & 13.9 & 13.1 & 11.8 & 12.6 \\
\hline Third dorsal spine & 22.1 & 22.9 & 22.4 & 24.5 & 23.2 & 23.7 & 21.9 & 21.6 & 23.2 \\
\hline Spine of second dorsal fin & 16.6 & 19.8 & 18.5 & 18.3 & 18.4 & 18.8 & 19.3 & 17.7 & 18.8 \\
\hline Longest dorsal soft ray & 26.2 & 27.6 & 28.3 & 29.6 & 29.4 & 28.8 & 29.0 & 28.5 & 27.1 \\
\hline First anal spine & 5.1 & 5.2 & 4.8 & 5.1 & 5.0 & 4.9 & 5.5 & 5.3 & 4.6 \\
\hline Second anal spine & 15.0 & 16.1 & 15.7 & 15.9 & 15.5 & 16.0 & 16.2 & 15.2 & 15.3 \\
\hline Longest anal ray & 23.3 & 24.8 & 24.6 & 24.5 & 23.9 & 25.0 & 25.1 & 24.1 & 25.0 \\
\hline Last anal ray & 15.8 & broken & 14.9 & 16.3 & 14.8 & 14.6 & 15.6 & 14.9 & 15.8 \\
\hline Caudal-fin length & 32.5 & 35.2 & 35.5 & 34.1 & 34.6 & 35.2 & 35.0 & 33.8 & 31.8 \\
\hline Caudal concavity & 9.6 & 11.1 & 10.9 & 11.1 & 10.7 & 10.9 & 10.9 & 10.1 & 9.8 \\
\hline Pectoral-fin length & 26.2 & 26.6 & 26.3 & 27.0 & 26.2 & 26.0 & 27.0 & 25.9 & 26.1 \\
\hline Pelvic-spine length & 14.8 & 15.3 & 15.4 & 16.7 & 15.7 & 16.0 & 15.8 & 14.9 & 15.3 \\
\hline Pelvic-fin length & 25.7 & broken & 25.8 & 25.9 & 25.0 & 25.5 & 25.7 & 25.7 & 25.7 \\
\hline
\end{tabular}


mouth slightly inferior and moderately oblique, the gape forming an angle of about $25^{\circ}$ to horizontal axis of head and body; supramaxilla absent; posterior end of maxilla truncate, the corners rounded; a broad band of villiform teeth in jaws, narrowing posteriorly, none enlarged, those in upper jaw in a maximum of about 10 irregular rows, and those in lower jaw in a maximum of about 7 irregular rows; a narrow symphyseal gap in teeth at front of upper jaw, its width about one-eighth pupil diameter; no gap in teeth at front of lower jaw; vomer with a $\mathrm{V}$-shaped patch of villiform teeth in 2 to 3 rows; palatines with a narrow band of villiform teeth in 1-3 irregular rows. Sides of free part of tongue parallel, the front strongly rounded. Gill raker at angle and adjacent one on lower arch longest, 2.6 in orbit diameter of holotype.

Opercular spine at level of center of eye, flat, and acute, followed by bluntly pointed flap of opercular membrane; free margin of preopercle finely serrate except about anterior half of ventral edge, the largest serrae on broadly rounded corner, the serrae 52 (3553 , increasing, in general, with growth); preopercular ridge smooth (cteni of scales overlapping edge of ridge may make it seem very finely serrate); edge of suborbital smooth; posterior edge of posttemporal usually with a few serrae (three on one side of holotype, none on other). Anterior nostril a short membranous tube, higher posteriorly, in a depression slightly below level of center of eye, about one-third orbit diameter in front of edge of orbit; posterior nostril a round to oval opening dorsoposterior to anterior nostril, the internarial distance about one-third pupil diameter; a broad slitlike aperture below and parallel to nostrils, and three broad slitlike openings directed ventrally on lower edge of snout; a pair of large pores on chin, one on each side of anterior end of isthmus; numerous small sensory pores dorsally on head, on snout, subopercle, and preopercle, and numerous small sensory papillae around eye, in nasal depression, and on preopercular flange.

Scales finely ctenoid; scales on nape extending foward to a vertical at posterior edge of preopercle; opercle with eight large scales, the largest a little bigger than largest scales of body, and three small scales at dorsoposterior edge; preopercular ridge rimmed by eight scales, the three lower scales preceded by two large scales; one median scale between dorsal fins, with overlapping scales from the side beneath it; no scales on fins except small scales on base of caudal fin; a midventral scaly process of about eight scales extending posteriorly from between bases of pelvic fins, its length nearly half length of pelvic spines.

Origin of first dorsal fin over second to third lateral-line scales, the predorsal distance 2.35 (2.35-2.4) in SL; spines of fins strong; first dorsal spine very short, 8.95 (7.4-9.4) in head; second dorsal spine $3.35(2.75-3.3)$ in head; third dorsal spine longest and thickest, $1.75(1.6-1.8)$ in head; spine of second dorsal fin $2.3(2.0-2.2)$ in head; first dorsal soft ray longest, $1.45(1.3-1.5)$ in head; origin of anal fin below base of second dorsal soft ray, the preanal distance $1.6(1.6-1.65)$ in head; first anal spine very short, $7.4(7.05-8.3)$ in head; second anal spine 2.55 (2.4-2.6) in head; first or second anal soft ray longest, 1.65 (1.5$1.65)$ in head; last anal soft ray $2.4(2.4-2.7)$ in head; caudal fin slightly forked with broadly rounded lobes, its length $3.05(2.8-3.15)$ in SL, the caudal concavity $4.0(3.55-3.85)$ in head; third or fourth pectoral ray longest, $1.45(1.45-1.55)$ in head; origin of pelvic fins below upper edge of pectoral-fin base, the prepelvic distance $2.65(2.6-2.75)$ in SL; pelvic spine $2.6(2.35-2.7)$ in head; first or second pelvic soft ray longest, $1.5(1.45-1.55)$ in head.

Color of holotype in alcohol: body brown with seven dark brown stripes equal to or narrower than paler interspaces on upper two-thirds of deepest part of body, the caudal peduncle fully striped; upper five stripes continuing anteriorly onto dorsal half of head; a short submarginal dark brown bar on operculum anterior to pectoral-fin base; median and pelvic fins translucent dusky, the second dorsal and anal fins with a brown stripe from anteriorly in base of fin to tip of last ray; pectoral fins pale with a dusky bar at base; digestive tract black, the peritoneum pale.

When fresh, the pale part of the body of 
the holotype was iridescent pink, and the head silvery with pink and green iridescence; the stripes were reddish brown, and the bar on the opercle was black; soft rays of the fins were dusky pink, the pink color most evident on the first rays of the second dorsal, anal, and pelvic fins, and the upper and lower edges of the caudal fin.

etymology: This species is named $A p o-$ gon sinus from the Latin for bay or recess, in reference to its being found only in wellprotected bays.

remarks: Apogon sinus was collected at only three stations in the Marquesas, one in Hiva $\mathrm{Oa}$ and two in Nuku Hiva. All were in very shallow water (one from a tide pool) at the head of deep bays.

With its unique pattern of seven narrow dark stripes on the body, but none on the ventral third of the deeper part of the body, Apogon sinus seemed to lack any close relatives. However, its occurrence in such shallow protected water prompted a comparison with A. taeniophorus Regan, which lives in the same habitat. The latter is found throughout the Indo-Pacific region from the Red Sea and coast of East Africa to the Pitcairn Islands, but not the Hawaiian Islands or Marquesas. It was soon apparent that $A$. taeniophorus is the probable sister species. It has the characteristic short black bar posteriorly on the opercle before the pectoral-fin base, dark digestive tract, slightly inferior mouth, same structure of the preopercular edge and ridge, and shares the counts of 14 pectoral rays and 4 median predorsal scales. Among other darkstriped species of Apogon that have been confused, A. taeniophorus and A. cookii Macleay have the lowest number of gill rakers, 17-19 (Randall \& Lachner 1986: table 1). The counts for $A$. sinus are 16-17. In addition to the obvious difference in color pattern and the slightly lower number of gill rakers, $A$. sinus differs from $A$. taeniophorus in having a deeper body. The depth of specimens of $A$. sinus varies from 2.6 to 2.9 in the SL, compared with 2.8-3.2 for specimens of $A$. taeniophorus of the same size range. Also it has a broader interorbital space, the least width 4.2-4.45 in head, compared with $4.5-5.35$ for A. taeniophorus.
Pseudamiops phasma Randall, n. sp. Figure 5, Table 4

Pseudamiops sp. Randall, 1985:471 (Marquesas).

HOLOTYPE: вРвм 12651, female, $33.7 \mathrm{~mm}$, Marquesas Islands, Nuku Hiva, Taiohae Bay, E side at head of bay, large heads of Porites with sand, rubble, and Halimeda between, $2.5 \mathrm{~m}$, rotenone, J. E. Randall, 19 May 1971.

PARATYPE: USNM $359802,34.0 \mathrm{~mm}$, Marquesas Islands, Tahuata, Hana Hevane Bay, rotenone, J. J. Magnuson, Charles $H$. Gilbert Cruise 54, 1 October 1961.

Diagnosis: Dorsal-fin rays VI, $8+\mathrm{I}, 8$; anal-fin rays II,8; pectoral-fin rays 19 ; scales thin, cycloid, highly deciduous, about 25 in longitudinal series; lateral line not detected; a sharp, downward-projecting bony process posteriorly on ventral margin of maxilla, body very elongate, the depth 4.3-4.5 in SL; lower two-thirds of posterior margin of preopercular very finely serrate, the broadly rounded corner irregular and notched; caudal fin rhomboid, 3.0 in SL; body largely transparent in life.

DESCRIPTION: Dorsal-fin rays VI, $8+\mathrm{I}, 8$; anal-fin rays II,8; all dorsal and anal soft rays branched, the last to base; pectoral-fin rays 19 (upper three and lower two or three unbranched); pelvic-fin rays I,5; principal caudal-fin rays 17 , the upper and lower unbranched; upper procurrent caudal-fin rays 7 (8), the most posterior segmented; lower procurrent caudal-fin rays 6 (7), the most posterior segmented; gill rakers $4+13(4+$ 12), $2+8$ developed; pseudobranchial filaments rudimentary; branchiostegal rays 7 ; vertebrae $10+14$; supraneural (predorsal) bones absent.

Body very elongate, the depth 4.3 (4.5) in SL, and strongly compressed, the width 2.2 (2.3) in depth; head length 3.05 (3.0) in SL; snout length 3.6 (3.7) in head; eye diameter 4.25 (4.5) in head; orbit diameter 3.75 (3.85) in head; interorbital space strongly convex, the least bony width 5.55 in head; least fleshy interorbital width 3.05 (2.95) in head; caudal peduncle slender and long, the depth 2.75 in head, and the length 1.2 (1.15) in head (3.553.65 in SL). 


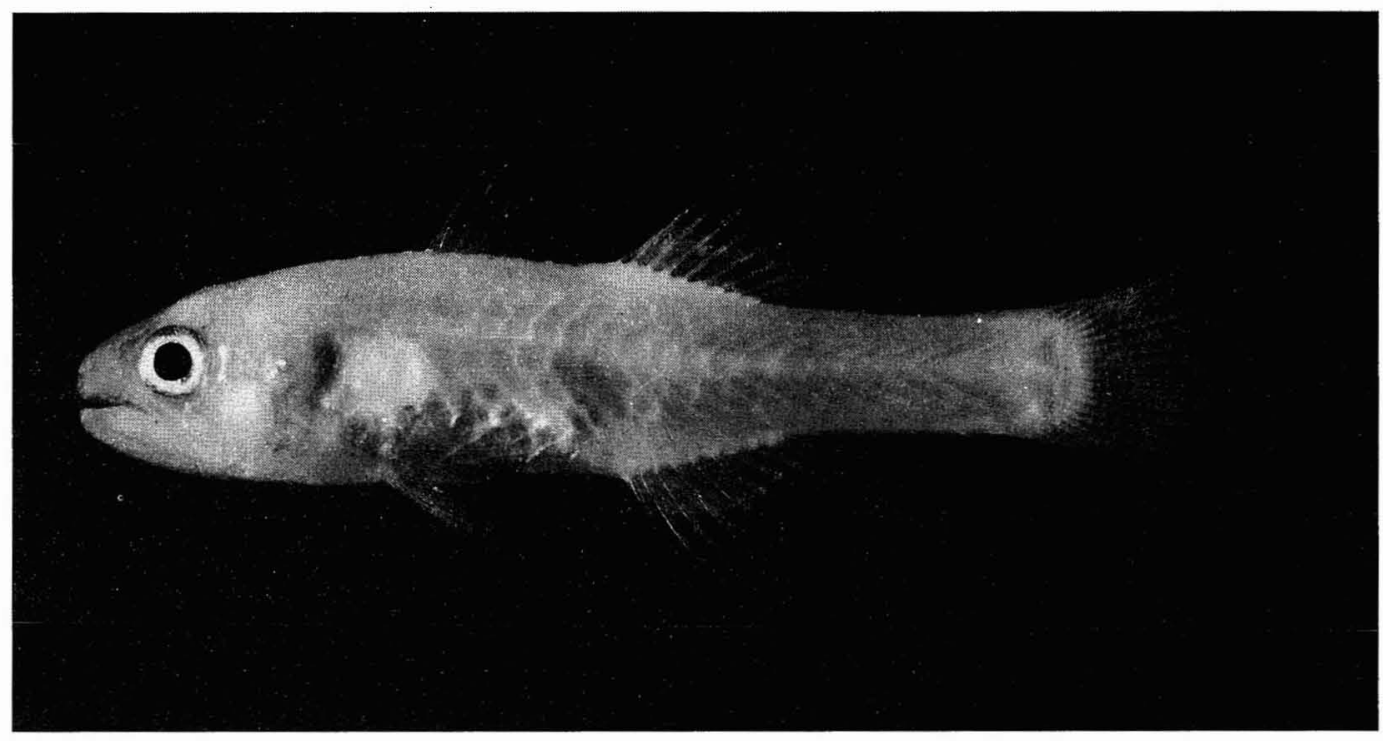

Figure 5. Holotype of Pseudamiops phasma, врвм 12651, 33.7 mm, Nuku Hiva, Marquesas Islands.

Mouth large, the maxilla extending beyond a vertical at posterior edge of orbit, the upper-jaw length 1.7 in head; mouth very slightly inferior and moderately oblique, the gape forming an angle of about $20^{\circ}$ to horizontal axis of head and body; supramaxilla absent; posterior end of maxilla truncate, the lower corner angling ventrally as a broad $\mathrm{V}$ shaped flat spine with an acute point; jaws with one to two irregular rows of small conical teeth, the front of upper jaw with three pairs of long slender canines that are sessile and inward-projecting; lower jaw with an inner row of larger, well-spaced, incurved teeth, those at front of jaw moderately large, those on side of jaw increasing to longest about halfway back in jaw; vomer with a $\mathrm{V}$-shaped patch of very small conical teeth in 2 rows; palatines with an irregular row of very small conical teeth. Free part of tongue a slender knob. First gill raker on lower limb longest (one at angle nearly as long), about 1.5 in orbit diameter.

Opercular spine not evident as a firm spine but present as a flexible angularity (slightly greater than $90^{\circ}$ ) at posterior end of opercle; opercular membrane broad, ending dorsally in a pointed flap; lower part of straight por- tion of preopercular margin with 16 (10) tiny, well-spaced serrae; corner and lower margin of preopercle irregular and notched; preopercular ridge smooth; edge of suborbital thin and membranous; 12 transverse rows of small papillae from front of interorbital space to posterior nape (the more posterior rows faint) and five incomplete longitudinal rows crossing first eight transverse rows, thus forming a crosshatch pattern; similar but more irregular rows of papillae dorsally on snout; same pattern of rows of papillae on cheek and preopercle, with five horizontal rows and seven vertical (starting on suborbital for the vertical rows). A series of five prominent pores in supraorbital series, the most anterior near front of snout; a large pore under posterior nostril; five prominent pores in mandibular series. Anterior nostril a small flaccid tube a pupil diameter anterior to center of eye; posterior nostril a large vertical slit just anterior to orbit, its lower edge at same level as anterior nostril; nasal chamber cavernous, the skin over its roof thin and sagging.

Scales thin, cycloid, and highly deciduous (nearly completely missing from both type specimens). 


\section{TABLE 4}

Proportional Measurements of Type Specimens of Pseudamiops phasma Expressed as Percentages of the Standard Length

\begin{tabular}{lccc}
\hline \hline & Holotype & Paratype \\
\cline { 2 - 2 } & BPBM & & USNM \\
Character & 12651 & & 359802 \\
\hline Standard length (mm) & 33.7 & 34.0 \\
Body depth & 23.2 & & 22.2 \\
Body width & 10.4 & 9.8 \\
Head length & 32.8 & & 33.2 \\
Snout length & 9.1 & 8.9 \\
Eye diameter & 7.7 & 7.4 \\
Orbit diameter & 8.8 & 8.6 \\
Interorbital width & 5.9 & 6.0 \\
Caudal-peduncle depth & 11.9 & 12.0 \\
Caudal-peduncle length & 27.5 & 28.3 \\
Upper-jaw length & 19.3 & 19.4 \\
Predorsal length & 38.5 & 38.1 \\
Preanal length & 56.1 & 53.4 \\
Prepelvic length & 31.7 & 31.5 \\
First dorsal spine & 12.5 & 13.8 \\
Second dorsal spine & 13.6 & 15.2 \\
Third dorsal spine & broken & 15.9 \\
Spine of second dorsal fin & 11.4 & 11.9 \\
Longest dorsal ray & 19.5 & 20.7 \\
First anal spine & 4.3 & 4.4 \\
Second anal spine & 9.9 & 10.9 \\
Longest anal ray & 19.4 & 19.9 \\
Caudal-fin length & 32.3 & 33.4 \\
Pectoral-fin length & 26.8 & 29.4 \\
Pelvic-spine length & 10.5 & 10.6 \\
Pelvic-fin length & 18.8 & 20.8 \\
\hline
\end{tabular}

Origin of first dorsal fin above base of middle pectoral rays, the predorsal distance 2.6 in SL; spines of fins very slender and flexible; first dorsal spine 2.6 (2.4) in head; second dorsal spine 2.4 (2.2) in head; third dorsal spine (2.1) in head; spine of second dorsal fin 2.85 (2.8) in head; first dorsal soft ray longest, 1.7 (1.6) in head; origin of anal fin below base of first dorsal soft ray, the preanal distance $1.8(1.85)$ in head; first anal spine very short, 7.65 (7.55) in head; second anal spine 3.3 (3.0) in head; first or second anal soft ray longest, 1.7 (1.6) in head; caudal fin rhomboid, its length 3.05 (3.0) in SL; pectoral fins long and pointed, the middle rays longest, 1.2 (1.15) in head, 3.75 (3.4) in $\mathrm{SL}$; origin of pelvic fins slightly anterior to pectoral-fin base, the prepelvic distance 3.15 in SL; pelvic spine 3.1 in head; first or second pelvic soft ray longest, 1.75 (1.6) in head.

Color of holotype in alcohol pale yellowish; peritoneum slightly dusky (finely dotted with small melanophores); digestive tract pale. The only color note with the specimen, "largely transparent in life."

etymology: This species is named Pseudamiops phasma from the Greek for phantom or aparition, in reference to its transparency.

ReMarks: The Indo-Pacific subfamily Pseudaminae consists of the genera Pseudamia Bleeker, Gymnapogon Regan, and Pseudamiops Smith. It was defined by Fraser (1972) as having $0-4$ epipleurals on the pleurals, unique shape of the neurocranium, no basisphenoid, two epurals, no supramaxilla, one opercular spine, 0-2 supraneural bones, and lateral line incomplete or absent. In addition, one should add the rows of sensory papillae at right angles on the head and the presence of deciduous cycloid scales (or absence of same). The species of Gymnapogon lack scales, but those of Pseudamiops may have lost so many scales as to appear naked. Gymnapogon is also distinct in having a large spine on the edge of the preopercle near the angle, and Pseudamiops is unique in having a downwarddirected spine posteriorly on the maxilla.

Pseudamiops is known from three species in addition to the one described herein: the type species, P. pellucidus Smith, 1954; $P$. gracilicauda (Lachner in Schultz and collaborators, 1953), and P. diaphanes Randall, 1998. Pseudamiops pellucidus from the coast of East Africa is distinct in having 9 anal soft rays, 14 pectoral-fin rays, 33 scales in longitudinal series, and long, slender canines in the jaws and on the vomer. Pseudamiops gracilicauda, described from the Marshall Islands and recorded later from Samoa (Wass 1984) and Rapa (Randall et al. 1990), has $15-16$ pectoral-fin rays and two stout serrae at the corner of the otherwise smooth preopercle. Pseudamiops diaphanes from the Hawaiian Islands has a finely serrate preopercle and 16-18 pectoral rays; it is the closest to $P$. phasma (which has 19 pectoral rays). In addition to having one additional pectoral-fin ray, $P$. phasma differs in having a shorter head (3.0-3.05 in SL, compared with $2.75-2.95$ for $P$. diapbanes), a 
broader interorbital (fleshy width 2.95-3.05 in head, compared with $3.1-3.65$ for $P$. diaphanes), and a deeper caudal peduncle (2.75 in head, compared with 2.9-3.5 for $P$. diaphanes).

\section{ACKNOWLEDGMENTS}

Thanks are due the collectors whose specimens are listed among the types of the species described above. Eugenia B. Böhlke loaned a paratype of Apogon relativus from the Academy of Natural Sciences of Philadelphia, and Mary Anne Rogers one from the Field Museum of Natural History. David Catania of the California Academy of Sciences and David G. Smith of the National Museum of Natural History provided information on the holdings of $A$. semiornatus in their respective institutions. Loreen R. O'Hara and David W. Greenfield took $\mathrm{X}$ rays of type specimens.

\section{Literature Cited}

Allen, G. R. 1997. Marine fishes of the Great Barrier Reef and South-East Asia, 3rd ed. Western Australian Museum, Perth.

Eichler, D., and R. F. Myers. 1997. Korallenfische Zentraler IndoPazifik. Jahr Verlag, Hamburg.

Fowler, H. W. 1928. The fishes of Oceania. Mem. B. P. Bishop Mus. 10: iii + 486 pp.

. 1938. The fishes of the George Vanderbilt South Pacific Expedition, 1937. Monogr. Acad. Nat. Sci. Phila., no. 2: $\mathrm{v}+349 \mathrm{pp}$.

Fraser, T. H. 1972. Comparative osteology of the shallow water cardinal fishes [Perciformes: Apogonidae] with reference to the systematics and evolution of the family. Ichthyol. Bull. J. L. B. Smith Inst. Ichthyol., no. 34:1-105.

Herre, A. W. 1936. Fishes of the Crane Pacific Expedition. Field Mus. Nat. Hist. Publ. Zool. Ser. 21:1-472.

Hombron, J. B., and H. Jacquinot. 1853. Poissons. Pages 31-56 in Vol. 3, part 2 of
J. S. C. Dumont d'Urville, Voyage au Pöle Sud et dans l'Océanie sur les corvettes "L’Astrolabe" et "La Zélée" ... pendant 1837-40. Gide et J. Baudry, Paris.

Myers, R. F. 1999. Micronesian reef fishes. Coral Reef Graphics, Guam.

Randall, J. E. 1985. Fishes. Pages 462-481 in B. Delasalle, R. Galzin, and B. Salvat, eds. Fifth International Coral Reef Congress, Tahiti, 27 May-1 June 1985. Vol. 1. French Polynesian coral reefs. Antenne Museum-Ecole Pratíque des Hautes Études, Moorea, French Polynesia.

- 1998. Review of the cardinalfishes (Apogonidae) of the Hawaiian Islands, with descriptions of two new species. Aqua 3 (1): 25-38.

Randall, J. E., and J. L. Earle. In press. Annotated checklist of the shore fishes of the Marquesas Islands, with 49 new records. Bishop Mus. Occas. Pap.

Randall, J. E., and E. A. Lachner. 1986. The status of the Indo-West Pacific cardinalfishes Apogon aroubiensis and A. nigrofasciatus. Proc. Biol. Soc. Wash. 99 (1): 110120.

Randall, J. E., C. L. Smith, and M. N. Feinberg. 1990. Report on fish collections from Rapa, French Polynesia. Am. Mus. Novit., no. 2966:1-42.

Schultz, L. P., and collaborators. 1953. Fishes of the Marshall and Marianas Islands. Bull. U.S. Natl. Mus. 202, vol. 1: xxxii + 685 pp.

Seale, A. 1906. Fishes of the South Pacific. Occas. Pap. Bernice Pauahi Bishop Mus. 4 (1): 3-89.

Smith, J. L. B. 1954. Apogonid fishes of the subfamily Pseudaminae from South-East Africa. Ann. Mag. Nat. Hist., ser. 12, vol. 7:775-795.

Springer, V. G. 1982. Pacific Plate biogeography, with special reference to shorefishes. Smithson. Contrib. Zool. 367: iv +182 .

Wass, R. C. 1984. An annotated checklist of the fishes of Samoa. NOAA Tech. Rep., NMFS SSRF no. 781: v +43 pp. 